\title{
The Formation of the Student's Objectivity in the University Educational Process
}

\author{
Kariyev A. D.*1, \\ Kodoeva A. C. ${ }^{2}$ \\ Fadeeva V. V. ${ }^{3}$ \\ Grigorev A. N. ${ }^{4}$ \\ Akhmetov T. ${ }^{5}$ \\ Sardarova $\mathrm{Z}^{6}$ \\ Yegenissova A. K. ${ }^{7}$ \\ Zhubangalieva G. G. ${ }^{8}$
}

\section{Journal for Educators, Teachers and Trainers, Vol. 11 (1)}

\author{
https://jett.labosfor.com/
}

Date of reception: 01 March 2020

Date of revision: 01 June 2020

Date of acceptance: 01 August 2020

Kariyev A. D., Kodoeva A. C., Fadeeva V. V., Grigorev A. N., Akhmetov T., Sardarova Z, Yegenissova A. K \& Zhubangalieva G. G (2020). The Formation of the Student's Objectivity in the University Educational Process the use of electronic educational resources. Journal for Educators, Teachers and Trainers, Vol. 11(1). 13 - 18.

\footnotetext{
${ }^{1}$ Master in pedagogical sciences, acting deputy Dean for research and innovation of the higher school of Pedagogy and psychology, Kazakh National Women's Teacher Training University, Republic of Kazakhstan, Almaty.

${ }^{2}$ Candidate of Philological Sciences, Department of Socio-Economic and Humanitarian Disciplines, Kaliningrad branch of the St. Petersburg University of the Ministry of Internal Affairs of the Russian Federation, Russia, Kaliningrad region.

Doctor of Pedagogical Sciences, Professor of the Department of Administrative and Legal Disciplines, Kaliningrad branch of the St. Petersburg University of the Ministry of Internal Affairs of the Russian Federation, Russia, Kaliningrad region, Kaliningrad city.

$\mathrm{PhD}$ in Law, Doctor of Pedagogical Sciences, associate professor, Head of Department of Administrative and Legal Disciplines, Kaliningrad branch of the St. Petersburg University of the Ministry of Internal Affairs of the Russian Federation, Russia, Kaliningrad region.

Doctor of Pedagogical Sciences, Professor, Vice-rector, Department of Pedagogy, Kostanay State Pedagogical University, Kostanay, Kazakhstan.

${ }^{6}$ Doctor pedagogical sciences, Republican Institute for Advanced Studies of senior and scientific- pedagogical workers of the education system of the, Republic of Kazakhstan.

${ }^{7}$ candidate of pedagogical science, Caspian State University of Technologies and Engineering named after Sh. Yessenov, Faculty of Pedagogy, Department of Pedagogical Technologies, Kazakhstan, Aktau.

${ }^{8}$ Senior teacher, Department of Pedagogy Laboratory, Kh. Dosmukhamedov Atyrau University, Atyrau, Kazakhstan.
} 


\title{
Journal for Educators, Teachers and Trainers, Vol. 11 (1) \\ ISSN 1989 - 9572 \\ https://jett.labosfor.com/
}

\section{The Formation of the Student's Objectivity in the University Educational Process}

Kariyev A. D.*1, Kodoeva A. C. ${ }^{2}$, Fadeeva V. V. ${ }^{3}$, Grigorev A. N. ${ }^{4}$, Akhmetov T. ${ }^{5}$, Sardarova Z. ${ }^{6}$, Yegenissova A. K. ${ }^{7}$, Zhubangalieva G. G. ${ }^{8}$

${ }^{1}$ Master in pedagogical sciences, acting deputy Dean for research and innovation of the higher school of Pedagogy and psychology, Kazakh National Women's Teacher Training University, Republic of Kazakhstan, Almaty.

${ }^{2}$ Candidate of Philological Sciences, Department of Socio-Economic and Humanitarian Disciplines, Kaliningrad branch of the St. Petersburg University of the Ministry of Internal Affairs of the Russian Federation, Russia, Kaliningrad region.

Doctor of Pedagogical Sciences, Professor of the Department of Administrative and Legal Disciplines, Kaliningrad branch of the St. Petersburg University of the Ministry of Internal Affairs of the Russian Federation, Russia, Kaliningrad region, Kaliningrad city.

$\mathrm{PhD}$ in Law, Doctor of Pedagogical Sciences, associate professor, Head of Department of Administrative and Legal Disciplines, Kaliningrad branch of the St. Petersburg University of the Ministry of Internal Affairs of the Russian Federation, Russia, Kaliningrad region.

Doctor of Pedagogical Sciences, Professor, Vice-rector, Department of Pedagogy, Kostanay State Pedagogical University, Kostanay, Kazakhstan.

${ }^{6}$ Doctor pedagogical sciences, Republican Institute for Advanced Studies of senior and scientific- pedagogical workers of the education system of the, Republic of Kazakhstan.

${ }^{7}$ candidate of pedagogical science, Caspian State University of Technologies and Engineering named after Sh. Yessenov, Faculty of Pedagogy, Department of Pedagogical Technologies, Kazakhstan, Aktau.

${ }^{8}$ Senior teacher, Department of Pedagogy Laboratory, Kh. Dosmukhamedov Atyrau University, Atyrau, Kazakhstan.

Email ID: education.com.kz@gmail.com

\begin{abstract}
In this article, we highlight and consider one of the directions for improving the system of training specialists in higher education - the formation of student subjectivity in the educational process of the university. It should be emphasized that this task is interdisciplinary and requires the integration of the efforts of many specialists: teachers, psychologists, sociologists, etc. The author describes the main interactive methods used in teaching practice: the "Workshop of the Future" method, the case-study method, the "Decision tree" method, and the educational discussion. Also in the article, the author revealed the goal of interactive learning, which is to create comfortable learning conditions in which each student can feel his success and intellectual competence, which will allow him to simulate life and professional situations from pedagogical practice, to find a solution to the problem based on an analysis of the circumstances and the corresponding situation; to contribute to the formation of professional skills and abilities, to cultivate humanistic values in him, help to create an atmosphere of interaction and cooperation.
\end{abstract}

Keywords: student subjectivity, interactive teaching, interactive teaching methods, "Workshop of the Future" method, case-study method, "Decision tree" method, educational discussion. 


\section{INTRODUCTION}

The relevance of the study of this problem is due to the fact that Kazakhstani society at the present stage of development has a particularly acute need for independent, creative and active individuals (State Program for the Development of Education of the Republic of Kazakhstan for 2011-2020). Such a person is able to realistically assess the life situation, his own intellectual and physical characteristics, sets himself high, but real goals, finds effective means to achieve them. And it is precisely such personality traits that modern primary, secondary and higher schools should form.

One of the ways to implement modern tasks of training future teachers is to create a special interactive educational environment in universities.

Despite the available scientific research in the direction of interactive learning, the development and application of lesson scenarios based on the interactive interaction of participants in the educational process remains an urgent task of modern pedagogy. The use of interactive technologies contributes to better adaptation of students to future professional activities, helps to motivate their learning, promotes socialization and professional development of everyone, makes it possible to test in practice, develop and integrate formed beliefs, skills, abilities, abilities.

In pedagogical practice, a modern educational subject is implemented - the subjective paradigm (when both the teacher and the student are equal partners of the educational process). The purpose of the interactive process is to change and improve the behavior patterns of its participants. Interactivity in learning - the ability to interact in the mode of conversation, dialogue, action. Analysis of recent studies and publications allows us to note that the problem of using innovative forms of organizing education in higher education, its individual aspects, both in Kazakhstan and abroad, have devoted their scientific research to domestic scientists and teachers. The work of Zh.K. Kaikenova (2008) is devoted to the disclosure of the problems of introducing interactive technologies and methods into pedagogical practice. However, the issue of the effective use of interactive technologies and methods in higher institutions, in particular, the use of interactive methods in the practice of higher education for the formation of students' subjectivity, remains insufficiently studied.

\section{MATERIALS AND METHODS}

The purpose of the article is to reveal the features of the use of interactive technologies and methods in the formation of students' subjectivity.

In the context of the humanistic educational paradigm, the position of the teacher, who becomes an organizer, assistant and consultant, one of the sources of information - a subject of learning on the path of cognition, is also seen as fundamentally different. In addition to these roles, the teacher also acts as a facilitator, which provides, according to K. Rogers (1994), support, assistance and at the same time stimulating the process of development and self-development of the student's personality. The student must show activity, independence and responsibility, the ability to move freely along the path of his personal growth.

One of the conditions for effective professional training and continuous self-improvement of a person is the formation of a student's subjectivity as a systemic quality that ensures continuous progressive self-development and its productive self-realization in the educational space.

According to a number of researchers, subjectivity as an integral quality of a personality reveals the orientation of a person's development towards improvement, towards its peak - "acme". Subjectivity develops in practice. The basis for the formation of subjectivity, the subjective position of an individual is its activity, the ability to organize life time.

According to A.A. Derkach (2015), "subjectivity is an integrative personal quality that reflects a person's activity in setting and achieving life goals, awareness of his motives and potentials, inner freedom and creativity, and ensures the processes of self-determination in choosing a life trajectory, self-transformation in personal and professional growth and self-realization in activity".

S.S. Kashlev (2002) considers the student's subjectivity as a state of personal and professional development, manifested in his ability to successfully adapt in a sociocultural environment, the possibility of productive pedagogical interaction with participants in the educational process, as well as in his understanding of the responsibility for creating conditions for his development.

The subjectivity of a student is an integrative personal quality, which is characterized by the student's activity, first of all, an internal focus on himself, that is, the definition of goals, tasks, the formation of motives for activity, 
etc., as well as an orientation towards the outside world, which is determined by the readiness to make the right decisions in non-standard life situations (Kariyev, Turganbayeva, Slambekova et al., 2014).

Practice shows that traditional teaching in universities with its standard forms, methods, means, content, goals, learning objectives does not sufficiently contribute to the formation of students' subjectivity. Therefore, in the process of studying psychological and pedagogical disciplines with students of the specialty 5B010300"Pedagogy and Psychology", interactive teaching methods were tested, which were the most effective and meet the requirements of the university curricula.

\section{RESULTS AND DISCUSSION}

According to the authors of the scientific and methodological manual "Development and implementation of interactive technologies in higher education" edited by A.N. Nyudyurmagomedov, interactivity in education is associated with various forms of interaction between participants and the means of the pedagogical process. At the same time, three options for such interaction are possible: students with educational content presented in various ways of presenting material and individually differentiated form of work; with a teacher or structurallyorganized teaching aids in the mass perception of educational material and open interaction of students with each other in the course of group work.

Here are examples of interactive teaching methods that most fully meet the specified requirements and the effective formation of students' subjectivity:

The "Workshop of the Future" method promotes the activation of the educational process, develops motivation for learning, forms an assessment of the level of preparedness of students and the degree of mastery of the material, contributes to the development of critical thinking and the ability to solve assigned tasks.

The case-study method teaches to analyze the situation, contributes to the development of the ability to identify key issues, choose the right solutions and formulate a sequence of actions.

The "Decision Tree" method develops creative thinking, forms the student's ability to predict the expected result and, if necessary, make adjustments on his own, contributes to the development of the ability to look for new methods and techniques in the implementation of the intended goal.

The educational discussion develops personal and professional qualities, the ability to defend one's opinion reasonably, contributes to the development of the ability to conduct business communication and public speaking. Consider examples of the implementation of the above interactive teaching methods in the study of psychological and pedagogical disciplines with students of the specialty 5B010300- "Pedagogy and Psychology". In the process of studying the discipline "Modern educational technologies" we used one of the interactive teaching methods the "Workshop of the future" method (Berkenova, 2011) on the topic "The use of modern technologies as an indicator of the pedagogical competence of a teacher." This method was implemented in two stages. The students were divided into 2 groups. At the first stage, students had to answer the following questions: make a list of reasons for the following problematic questions: "When is a student not interested in learning?", "When is a teacher not interested in teaching?" After a little preparation, there was a discussion on these issues. At the second stage, students had to fill out the table "Comparative features of traditional and innovative teaching." The comparison of traditional and innovative teaching was carried out according to the following parameters: learning goals, motivation of students' cognitive activity in the classroom, teaching methods, motto and guiding principle of the teacher, teacher's position and behavior style, student's position and behavior style, communication, learning outcomes, assessment, reflection. The group had 20 minutes to discuss the solution to the problem. The representative of each group presented the results of the comparative analysis with arguments, after which the whole group discussed the results of the work of the groups. This method contributed to the activation of students 'attention in the classroom, as well as the development of students' critical thinking.

The next method that was used in the lesson is the case-study method. This method was applied in a practical lesson in the discipline "Inclusive education" on the topic "International experience in organizing inclusive education." The structure of the case includes: introduction (relevance and problem statement), problem, materials for solution (structured by topic). The case may also include problematic articles representing the opinions of various authors (Imramzieva, 2009).

This method allows you to develop an algorithm for making a decision, master the skills of studying a situation, develop an action plan, apply the obtained theoretical knowledge in practice, taking into account the points of view of other specialists, develops the student's qualities such as initiative, readiness to act in various conditions 
and the ability to flexibly respond to them. In the course of work on a case, students can offer several independent options for solving one problem.

The case-study method consisted of two stages: organizational and preparatory. According to the methodology for applying this method at the organizational stage, students discussed the situation proposed by the teacher. Speaker, opponent and expert were selected in the study group of students. The speaker was involved in organizing a discussion in the group and formulating a common opinion. The opponent's job was to listen carefully and clarify or formulate questions on the problem posed. The expert was asked to form a value judgment on the proposed position of each student in the group. At the preparatory stage, tasks were solved. Each student of the group was given the task to analyze a specific situation, offer their point of view, voice their solution algorithm and formulate a conclusion. Students were offered the following assignments:

1. Analyze the current state of inclusive education in Kazakhstan and Finland.

2. What positive results can you highlight on inclusive education in these countries?

3. What can be learned from the experience of organizing inclusive education in Finland?

This method contributes to the saturation of knowledge, the ability to understand situations, improves the personal and professional qualities of students in the process of individual and collective activities.

Consider the following interactive teaching method - the Decision Tree method (Rysbaeva, 2007). This method was used on a practical assignment when studying the topic "Organization of extracurricular activities at school" in the discipline "Theory and methodology of educational work". The "Decision Tree" method helps to find solutions to the problem, helps students analyze and better understand the decision-making mechanism. To implement this method, students were united into groups (5-6 people), each of which discusses the issue and makes a note on its own "tree" (sheet of paper). Groups exchange trees, adding new ideas. This method has been modified and changed in its name ("Sentence tree" and "Who is more?"). So, for the practical lesson, the students were offered the following task: come up with as many names of circles as possible for students of different ages; Place tree sticky notes on the board. The task contributed to the development of students' projective skills.

One of the productive interactive methods is educational discussion (Tursunova, 2008). This method was used by us in the lesson on the discipline "Image in the career of a teacher" while studying the topic "The strategy of communicative behavior". Students were asked to complete a creative task. They were independently divided into subgroups. The solution was presented by several authors in the form of a presentation and discussion on this topic. The speakers showed 20 slides on which the solution to the issue was presented. This form showed the level of preparedness of students. The discussion allowed not only to comprehensively and deeply solve the problem, but also encouraged the participants to think about it, define their position, learn to defend their point of view, realizing the right of others to have their own view of the problem.

\section{CONCLUSION}

Thus, the use of interactive teaching methods allows the individual to maximally identify internal inclinations that are important for future professional activities, and ensure the effective formation of the components of the student's subjectivity. Interactive methods encourage the strengthening of educational influences, since in the course of their application, students become more democratic, free in their statements, communicating with other people, learn to think critically, show readiness to solve complex professional problems, situations, show activity, initiative, exactingness, responsibility for their actions and deeds, humane personality traits.

\section{REFERENCES}

1. State Program for the Development of Education of the Republic of Kazakhstan for 2011-2020. Retrieved from http://control.edu.gov.kz/ru/gosudarstvennaya-programma-razvitiyaobrazovaniya-na-2011-2020-gody

2. Kaikenova, Zh.K. (2008). Interactive forms and methods of teaching civil servants: teaching aid. Astana.

3. Rogers. K. (1994). Formation of personality. A look at psychotherapy. Moscow: Progress.

4. Derkach, A.A. (2015). Professional subjectivity as a psychological and acmeological phenomenon. Akmeologiya, 4 (56), 9-19.

5. Kashlev, S.S. (2002). Pedagogical conditions for the development of student's subjectivity in the pedagogical process of the university. Proceedings of the second republican scientific-practical 
conference: University education: from effective teaching to effective teaching. Belarusian State University. Center for Educational Development Problems. Minsk: Propylaea.

6. Kariyev, A., Turganbayeva, B., Slambekova, T. (2014). Model of Formation of Teacher's Readiness to Learning on The Base of Interactive Methods as The Conditions of Creation of Students Abilities. Proceedings of 2nd Global Conference on Psychology Researches.

7. Berkenova, G.S. (2011). Interactive learning as a condition for improving the professional training of specialists in the university. Bulletin of Karaganda University. Series Pedagogy, 3, 65-71.

8. Imramzieva, S.D. (2009). Interactive learning technologies. Professional of Kazakhstan, 8, 63-64

9. Rysbaeva, A.K. (2007). Interactive learning as a factor in the successful educational activity of students. Bulletin of Kaz NPU named after Abai. Series of pedagogical sciences, 4, 26-29.

10. Tursunova, B.Zh. (2008). Interactive teaching technologies in higher education. Actual problems of the present. Series Pedagogy, 17, 74-77.

11. Abykanova, B., Kussainov, G. M., Mukhametkaly, M. M. (2020). Formation of communicative competence of students in the information educational environment of an urban school. Ad Alta Journal of Interdisciplinary Research, 10(1), 89-92.

12. Kussainov, G. M., Abdol E. D., Mukhambetov, Z. M. (2020). Information technologies as a determining factor of development of objects of social-infrastructural centers of the region. Ad Alta Journal of Interdisciplinary Research, 10(1), 97-99.

13. Abykanova, B., Bilyalova, Zh., Tashkeyeva, G. (2020). Professional competencies and methods for their formation in the university. Ad Alta Journal of Interdisciplinary Research, 10(1), 59-62

14. Abykanova, B., Yelezhanova, Sh., Koishigulova, L. et al. (2020). The use of modern information technologies in the educational process. Ad Alta Journal of Interdisciplinary Research, 10(1), 37-40.

15. Yegenissova, A. K., Tulenova, U., Aidnaliyeva, N. A. (2020). Methods and approaches in interactive learning. Ad Alta Journal of Interdisciplinary Research, 10, 35-40.

16. Li, A., Kudebayeva, G., Sardarova, Z. (2016). Socio-psychological profile of a person exposed to suicidal behavior. International Journal of Psychology, 1, 75-76. 